\title{
WtsE, an AvrE-Family Effector Protein from Pantoea stewartii subsp. stewartii, Causes Disease-Associated Cell Death in Corn and Requires a Chaperone Protein for Stability
}

\author{
Jong Hyun Ham, ${ }^{1,2}$ Doris R. Majerczak, ${ }^{1}$ Angel S. Arroyo-Rodriguez, ${ }^{1}$ David M. Mackey, ${ }^{2}$ and \\ David L. Coplin ${ }^{1}$ \\ ${ }^{1}$ Department of Plant Pathology, ${ }^{2}$ Department of Horticulture and Crop Sciences, The Ohio State University, \\ Columbus 43210-1087, U.S.A.
}

Submitted 26 October 2005. Accepted 22 May 2006.

\begin{abstract}
The pathogenicity of Pantoea stewartii subsp. stewartii to sweet corn and maize requires a Hrp type III secretion system. In this study, we genetically and functionally characterized a disease-specific (Dsp) effector locus, composed of $w t s E$ and $w t s F$, that is adjacent to the $h r p$ gene cluster. WtsE, a member of the AvrE family of effector proteins, was essential for pathogenesis on corn and was complemented by DspA/E from Erwinia amylovora. An intact Cterminus of WtsE, which contained a putative endoplasmic reticulum membrane retention signal, was important for function of WtsE. Delivery of WtsE into sweet corn leaves by an Escherichia coli strain carrying the hrp cluster of Erwinia chrysanthemi caused water-soaking and necrosis. WtsE-induced cell death was not inhibited by cycloheximide treatment, unlike the hypersensitive response caused by a known Avr protein, AvrRxo1. WtsF, the putative chaperone of WtsE, was not required for secretion of WtsE from $P$. stewartii, and the virulence of $w t s F$ mutants was reduced only at low inoculum concentrations. However, WtsF was required for full accumulation of $\mathrm{Wts} E$ within the bacteria at low temperatures. In contrast, WtsF was needed for efficient delivery of WtsE from $E$. coli via the Erwinia chrysanthemi Hrp system.
\end{abstract}

Additional keywords: DspB/F, Erwinia stewartii, Zea mays.

Gram-negative phytopathogenic bacteria utilize a Hrp type III secretion systems (TTSS) to deploy a variety of effector proteins into host cells (Alfano and Collmer 2004; Alfano et al. 2000). The number of known effectors has been rapidly growing due to genome-wide genetic screens and the availability of genome sequences for several bacterial pathogens. We now know that as many as 50 effectors may be deployed by a single pathogen (Alfano and Collmer 2004; Mudgett 2005). However, determining the function of individual effector proteins in virulence is still challenging, because many of them are functionally redundant and, therefore, do not appear to have an effect on pathogenicity when mutated. Nevertheless,

Corresponding author: David L. Coplin; E-mail: coplin.3@osu.edu

The nucleotide sequence data for the P. stewartii subsp. stewartii Hrp pathogenicity island is available in the GenBank database under accession number AF282857. recent studies on various types of effectors have elucidated their modes of action in plant cells, and many of them appear to be involved in suppressing defense responses elicited by other effectors or pathogen-associated molecular patterns (PAMPs) (Alfano and Collmer 2004; Mudgett 2005). To date, only a few effectors have been shown to individually produce symptoms on susceptible hosts (Badel et al. 2006; Boureau et al. 2006). As reviewed below, the conserved AvrE-family effectors are among the few that are required for full virulence of many phytopathogenic pseudomonads, erwinias, and pantoeas.

Pantoea stewartii subsp. stewartii (synon. Erwinia stewartii) causes Stewart's bacterial wilt and leaf blight of sweet corn and maize (Zea mays). This is the most serious bacterial disease of sweet corn in the north-central and eastern United States. The pathogen is transmitted by the corn flea beetle, Chaetocnema pulicaria, through feeding wounds and then grows both in the xylem vessels of the host plants, causing wilt, and in the intercellular spaces of the leaves, causing "water-soaked" lesions. The only identified pathogenicity factors for $P$. stewartii subsp. stewartii are the extracellular polysaccharide and the Hrp TTSS (Dolph et al. 1988; Frederick et al. 2001). We have characterized the hrp gene cluster and the adjacent diseasespecific (Dsp) effector region, which consists of wtsE and $w t s F$ (Frederick et al. 2001) and two additional genes, ORF1 and ORF2 (Fig. 1) (D. R. Majerczak, and D. L. Coplin, unpublished data). Mutations in wtsE resulted in complete loss of pathogenicity but did not affect the ability to elicit a hypersensitive response (HR) in tobacco leaves. wtsE encodes a 201$\mathrm{kDa}$ protein (1,835 amino acids [aa]) and $w t s F$ encodes a 15.6$\mathrm{kDa}$ (139 aa) protein. From its small size and acidic properties (theoretical isoelectric point $=4.8$ ), WtsF is likely to be a molecular chaperone for WtsE. ORF1 is highly homologous to the signaling domain of methyl-accepting chemotaxis proteins found in many gram-negative bacteria, and ORF2 is a pseudogene that is homologous to avrPpiB from Pseudomonas syringae pv. pisi, but neither ORF1 nor ORF2 appears to contribute to virulence in corn (D. R. Majerczak, and D. L. Coplin, unpublished data).

We previously reported (Frederick et al. 2001) that WtsE and WtsF have high aa identity to AvrE1 and AvrF from Pseudomonas syringae pv. tomato (Lorang and Keen 1995) and $\mathrm{DspA} / \mathrm{E}$ and DspB/F from Erwinia amylovora (Bogdanove et al. 1998b; Gaudriault et al. 1997). DspA/E, WtsE, and AvrE1 belong to the AvrE family of effector proteins that is conserved in many plant-pathogenic bacteria and even a plant growth- 
promoting rhizobacterium (Preston et al. 2001). Other members of this family include AvrE1 from Pseudomonas syringae pathovars tomato and syringae (Alfano et al. 2000), RopE from Pseudomonas fluorescens (Preston et al. 2001), DspE $\mathrm{E}_{P a g}$ from Pantoea agglomerans pv. gypsophilae (Mor et al. 2001), DspE $_{E p}$ from Erwinia pyrifoliae (GenBank AAS45452), and $\mathrm{DspE}_{\text {Eca }}$ from Erwinia carotovora subsp. atroseptica (Holeva et al. 2004). In Pseudomonas syringae pv. tomato, Erwinia amylovora, and P. agglomerans pv. gypsophilae, loss of AvrE1 or $d s p E$ either completely eliminates or decreases virulence (Badel et al. 2006; Bogdanove et al. 1998b; Gaudriault et al. 1997; Lorang et al. 1994; Mor et al. 2001), whereas lesions formed by Erwinia carotovora subsp. atroseptica $d s p E \mathrm{mu}-$ tants on potato were greatly reduced in length when low inocula levels were used to infect plants. (Holeva et al. 2004). In Pseudomonas syringae pv. tomato DC3000, AvrE1 is functionally redundant with HopM1; loss of both proteins reduces virulence (Badel et al. 2003, 2006), but complementation with either one can fully or partially restore it (DebRoy et al. 2004). These findings demonstrate that this family of effectors plays a key role in the pathogenicity of many different plant pathogens.

The mechanism by which any AvrE-family protein kills cells of host plants is still unknown and, depending on the host, may involve different types of responses. For example, Oh and Beer (2005) have reported that Erwinia amylovora DspA/E causes HR in Nicotiana benthamiana when it is transiently expressed by agroinfection. Similarly, Boureau and associates. (2006) have shown that transiently expressed DspA/E induces necrotic symptoms in both apple and tobacco leaves. Some effectors in this family are also capable of suppressing host defenses. DebRoy and associates (2004) demonstrated that AvrE1 and HopM1 (HopPtoM) from DC3000 suppress salicylic acid (SA)-dependent cell wall-associated defenses in Arabidopsis thaliana. Boureau and associates (2006) also reported that DspA/E delayed the expression of a defense marker gene, $P R l$.

The genes for the AvrE-family proteins are often adjacent to small open reading frames (ORF) encoding putative molecular chaperones, which may be important for effector function, secretion or stability. In Erwinia amylovora, DspA/E is secreted into the culture medium in a TTSS-dependent manner (Bogdanove et al. 1998a; Gaudriault et al. 1997) and loss of $\mathrm{DspB} / \mathrm{F}$ greatly reduces the amount of both extra- and intracellular DspA/E (Gaudriault et al. 2002). Consequently, Gaudriault and associates (2002) concluded that the primary role of $\mathrm{DspB} / \mathrm{F}$ is to stabilize $\mathrm{DspA} / \mathrm{E}$ in the bacterial cell before secretion.

In this study, we completed the genetic analysis of the $P$. stewartii subsp. stewartii wtsEF operon. We also confirmed that WtsE is secreted into culture supernatants in a Hrp-dependent manner and we determined the effect of $w t s F$ mutations on virulence and WtsE production. Finally, we demonstrated that WtsE causes water-soaking in sweet corn leaves, when delivered by an Escherichia coli strain via the Erwinia chrysanthemi Hrp secretion system.

\section{RESULTS}

Genetic and phenotypic analysis of the wtsEF operon.

We previously found that wtsE mutants were nonpathogenic but could still elicit an HR in tobacco (Frederick et al. 2001). However, subsequent sequencing of our putative transposon insertions in $w t s F$, which were mapped by restriction enzyme analysis, revealed that they were located at the extreme C-terminal end of $w t s E$ (data not shown). Additional $w t s E$ mutants and two $w t s F$ mutants were obtained as part of a separate study to isolate HrpL-regulated genes. We performed random miniTn5gus (Fouts et al. 2002) mutagenesis on wild-type strain DC283 and screened approximately 25,000 mutants for genes that were up-regulated by HrpL (J. H. Ham, D. R. Majerczak, and D. L. Coplin, unpublished data); then, the regions flanking the transposon insertion sites were sequenced. This mini-Tn5 transposon makes gus transcriptional fusions and contains stop codons in all reading frames just upstream of the $\beta$-glucuronidase (GUS) reporter gene. This approach resulted in 16 miniTn5gus insertions throughout the length of wtsE (12 of the 16 mutants are shown in Figure 1) and two that were located in $w t s F$ (Fig. 1, DM5040 and DM5073). Using these new mutants, we reaffirmed our previous conclusion that the $w t s E F$ region constitutes a single operon, which is transcribed from the $h r p$ box promoter (GGAACT-N ${ }_{15}$-CCACACAAA) preceding $w t s E$, and examined the phenotype of a nonpolar wts $E$ mutant and two transposon-induced $w t s F$ mutants.

The absence of apparent transcriptional terminators between $w t s E$ and $w t s F$ and the fact that the two new $w t s F::$ miniTn5gus insertions were HrpL-regulated suggested that both ORFs are transcribed as a single operon from $\mathrm{P}_{w t s E}$. However, when we analyzed the intergenic region, using the Neural Network Promoter Prediction program (NNPP, version 2.2) pro-
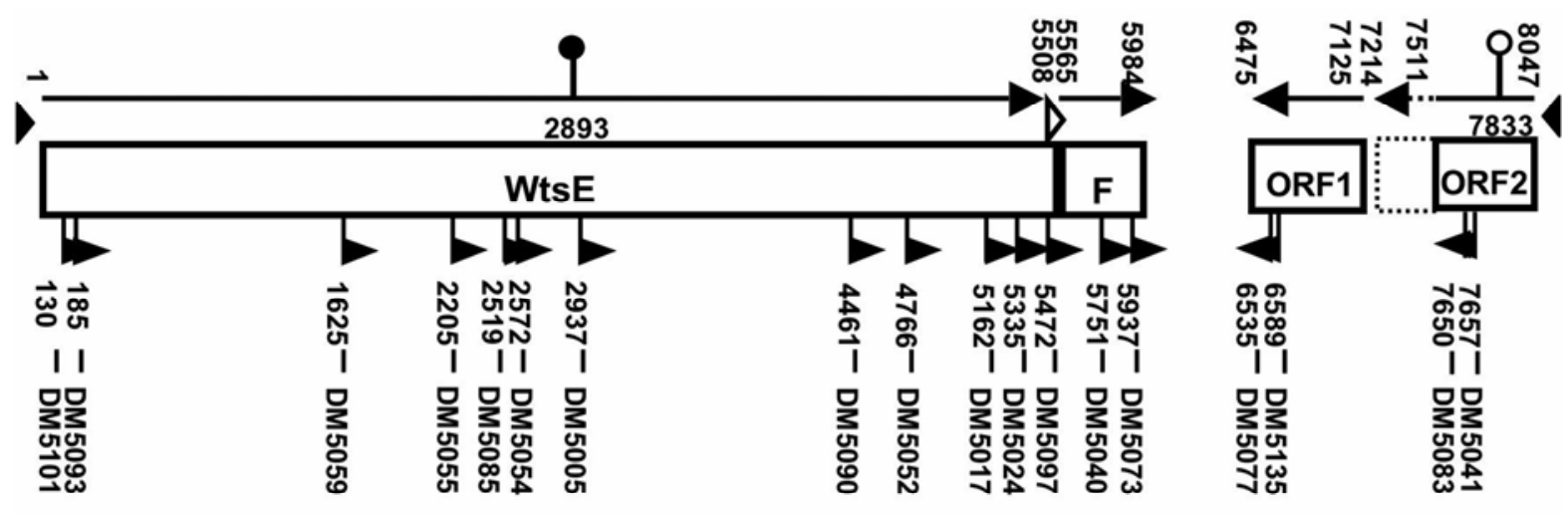

$1 \mathrm{~kb}$

Fig. 1. Genetic map of the disease-specific effector locus and Pantoea stewartii subsp. stewartii mutants used in this study. Arrows indicate the direction of transcription, and numbers indicate nucleotide sequence coordinates for the ends of each open reading frame and the position of insertion mutations. Mutant strain numbers are given below the coordinates. Filled flags indicate mini-Tn5gus insertions and the direction of the gus reporter gene in P. stewartii subsp. stewartii mutants obtained by screening for HrpL-regulated genes. The filled circle indicates the position of the aphT cassette in wtsE mutant AA005. Triangles indicate putative HrpL-dependent promoters (filled) and a putative $\sigma^{70}$ promoter (open). 
vided by the Berkeley Drosophila Genome Project website (Reese 2001), we found a potential $\sigma^{70}$ promoter sequence (TTGAAA-N ${ }_{18}$-ATTAAT) with a probability score of 0.92 that starts $17 \mathrm{bp}$ before the end of $w t s E$ (Fig. 1). To determine if this sequence could function as a secondary promoter, $0.5 \mathrm{~kb}$ of the $5^{\prime}$ untranslated region (UTR) of $w t s F$ was cloned into the promoter probe plasmid pFUS1 to create a $\mathrm{P}_{w t s}$-uidA transcriptional fusion (plasmid pDM2924). The expression of this fusion was measured in wild-type strain DC283 under both $h r p$-inducing (IM medium) and hrp-repressing (Luria-Bertani [LB] broth) conditions. Expression of $\mathrm{P}_{w t s} F^{-}$uidA was constitutively high in both IM and LB media $(15,140 \pm 4,747$ and $6,338 \pm 999$ GUS units, respectively). In contrast, $\mathrm{P}_{w t s E^{-}}$uidA expression in vector pL6GUSC (plasmid pDM2791) was induced in IM and repressed in LB (1,053 \pm 546 vs. $6.3 \pm 5.0$ GUS units), which is typical for $P$. stewartii subsp. stewartii hrp-box promoters (Merighi et al. 2003). Similarly, the expression of the $w t s F$-uidA transcriptional fusions in mutants DM5040 and DM5073 were compared with the wtsE-uidA fusions in mutants DM5101 and DM5005. The wtsE fusions were induced more strongly in IM than the wts $F$ fusions (17vs. 3-fold), and $w t s F$ expression was higher than that of $w t s E$ in LB broth (1,043 \pm 568 vs. $218 \pm 60$ GUS units). It therefore appears that $w t s F$ may be constitutively transcribed from its own promoter at basal levels and then expressed at higher levels upon activation of $\mathrm{P}_{w t s E}$ by HrpL.

To determine the phenotype of a nonpolar wtsE mutant, an aphT cassette (Galan et al. 1992) was inserted into the middle of the wtsE ORF (between M964 and A965) to construct AA005 (Fig. 1). This aphT cassette has a strong promoter that drives the expression of downstream genes. AA005 was nonpathogenic on sweet corn (Fig. 2) but still elicited the HR on tobacco, confirming our previous results. The virulence of AA005 was restored by pAA007 $w t s E F^{+}$in pseudostem inoculations (Fig. 2) and by plasmid pJH019, which carries only wtsE, in whorl inoculations. Disease severity (using a 0 to 3 scale) was $2.8 \pm 0.3$ for wildtype strain DC283, $0 \pm 0$ for AA005, and $2.6 \pm 0.4$ for AA005(pJH019). Differences between the complemented strains and DC283 were not significant at $P=0.05$.

The two new wtsF::mini-Tn5gus mutants, DM5040 with an insertion in the middle of the ORF and DM5073 with an inser-

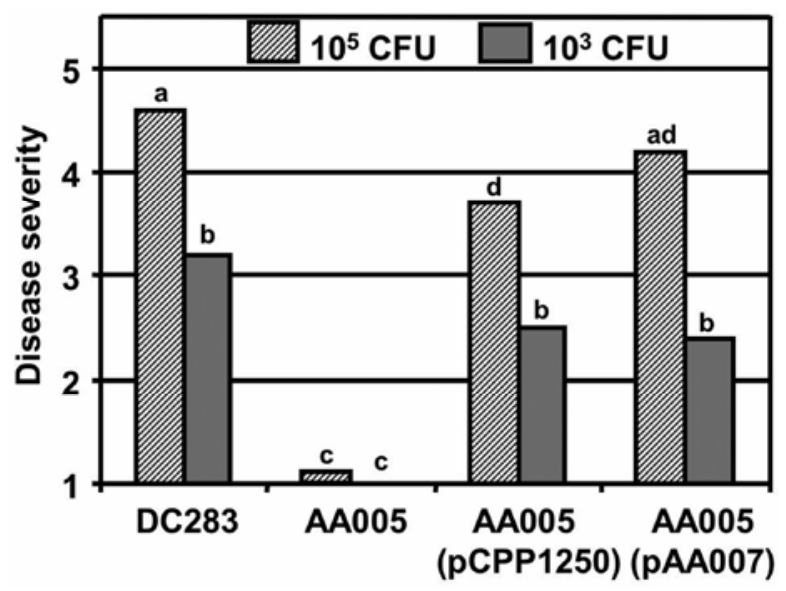

Fig. 2. Complementation of Pantoea stewartii subsp. stewartii wtsE mutant AA005 for virulence on sweet corn seedlings with $D s p A / E$ of Erwinia amylovora in plasmid pCPP1250 and wstEF in plasmid pAA007. DC283 is the wild-type parent strain. Plants were inoculated by placing either $10^{3}$ or $10^{5} \mathrm{CFU}$ on the stumps of decapitated seedlings. Disease severity was rated 8 days after inoculation on a scale of 1 to 5 . $1=$ no symptoms, $2=$ scattered lesions, $3=$ slight wilting, $4=$ severe wilt, and $5=$ dead. Each mean represents at least 15 replications. Bars topped by the same letter are not significantly different $(P=0.05)$. tion near the $3^{\prime}$ end, were as virulent as the wild-type parent strain when they were inoculated into corn seedlings at $10^{9}$ $\mathrm{CFU} / \mathrm{ml}$ using the whorl inoculation method (data not shown). However, when they were introduced into decapitated corn seedlings at 250 and $50 \mathrm{CFU} /$ plant, the $w t s F$ mutants were reduced in virulence (Fig. 3). The reduction in disease severity was most apparent at $50 \mathrm{CFU} /$ plant, suggesting that loss of $\mathrm{WtsF}$ affects infectivity rather than aggressiveness. It therefore appears that WtsF is either not absolutely necessary for WtsE translocation or it is functionally redundant with a similar chaperone-like protein.

WtsE is secreted in culture in a Hrp-dependent manner, and WtsF contributes to WtsE stability.

To demonstrate secretion of WtsE in culture, we grew $P$. stewartii subsp. stewartii strains in IM broth and induced high levels of hrp-gene expression by introducing plasmid pRF205, which overexpresses the HrpS transcriptional enhancer. WtsE was detected in our Western blots by cross-reacting antibodies to $\mathrm{DspA} / \mathrm{E}_{E a}$ (Fig. 4), so this antiserum was used in our experiments. When culture supernatants were concentrated by trichloroacetic acid precipitation, a band of the expected size for WtsE $(200 \mathrm{kDa})$ was present in the supernatant fraction from wild-type strain DC283 but not in the supernatants from AA005 and DM711, a hrpJ secretion mutant that served as a control for cell lysis (Fig. 4A). The wtsE::aphT mutant secreted a 113$\mathrm{kDa}$ cross-reacting protein, representing the $\mathrm{N}$-terminal half of WtsE (data not shown). These results indicated that WtsE is secreted in a hrp-dependent manner and that the $\mathrm{N}$-terminal half is sufficient for its secretion.

To determine the role of WtsF in WtsE production, we examined the relative amount of WtsE in cell pellets and culture supernatants from DC283 and two different wts $F$ mutants, DM5040 and DM5073. The WtsE bands detected by the chemiluminescence from immunoblots were quantified by densitometry, and peak areas were normalized for sample loading using other extracellular proteins, which were apparent in Coomassie-stained gels of the same samples. There was no difference between wild-type strain DC283 and the wtsF mutant strains in the amount of WtsE in either the supernatants or the cellular fractions when $P$. stewartii subsp. stewartii strains were grown at $28^{\circ} \mathrm{C}$ (data not shown). In contrast, WtsE levels in the supernatants and the cellular fractions from both $w t s F$ mutants were approximately 20 to $30 \%$ of those in wild-type strain DC283, when the bacteria were grown at $22^{\circ} \mathrm{C}$ (Fig. 4A and $\mathrm{B})$. However, there was no difference in the amounts of

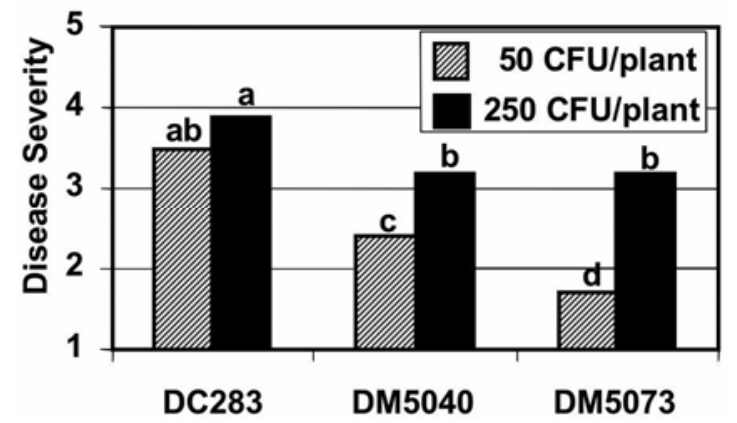

Fig. 3. Virulence of Pantoea stewartii subsp. stewartii wtsF mutants DM5040 and DM5073 on sweet corn seedlings. Plants were inoculated by placing either 50 or $250 \mathrm{CFU}$ on the stumps of decapitated seedlings, and disease severity was rated at 7 days after inoculation on a scale of 1 to 5.1 = no symptoms, 2 = scattered lesions, $3=$ slight wilting, $4=$ severe wilt, and $5=$ dead. Each mean represents at least 30 replications. Bars topped by the same letter are not significantly different $(P=0.05)$. Similar results were obtained from three or more independent experiments. 
other extracellular proteins relative to $\mathrm{WtsE}$ in DC283 at 22 or $28^{\circ} \mathrm{C}$, indicating that temperature did not affect protein secretion per se. Complementation of the wts $F$ mutants with plasmid $\mathrm{pWtsF}$ restored the amount of intracellular WtsE at $22^{\circ} \mathrm{C}$ to levels comparable to DC283 (Fig. 4C). These findings suggest that, at low temperatures, WtsF may protect WtsE from degradation within the bacterial cell and that the reduction of WtsE seen in the supernatants of $w t s F$ mutants is proportional to the lower levels found inside the cells.

\section{WtsE is homologous to other AvrE/DspE family proteins.}

The predicted aa sequence of WtsE was subjected to an updated bioinformatic analysis to find new homologs and potential functional motifs. GenBank searches were done with BLASTP 2.2.13 (Nov. 27, 2005) (National Center for Biotechnology Information, Bethesda, MD, U.S.A.) (Altschul et al. 1997). WtsE was most closely related to $\mathrm{DspE}_{P a g}(69.4 \%$ aa identity), $\operatorname{DspE}_{E p}(59.7 \%)$, and $\mathrm{DspA} / \mathrm{E}_{E a}(59.3 \%)$ but was only $37.0 \%$ identical to $\mathrm{DspE}_{E c a}$. It also had less homology to AvrE1 proteins from Pseudomonas syringae pathovars tomato $(27.1 \%)$, phaseolicola $(25.0 \%)$, and syringae $(24.9 \%)$ and RopE from Pseudomonas fluorescens (18.9\%). DebRoy and associates (2004) reported that two predicted proteins from the genome sequences of Ralstonia solanacearum and Xanthomonas campestris pv. campestris (GenBank accession numbers NP_522840 and NP_636464, respectively) were homologs of Pseudomonas syringae pv. tomato DC3000 AvrE1; however, these were not detected by our BLAST search for WtsE homologs. Hence, we directly compared these two predicted proteins with WtsE and found that they have only about $14 \%$ identity to it.
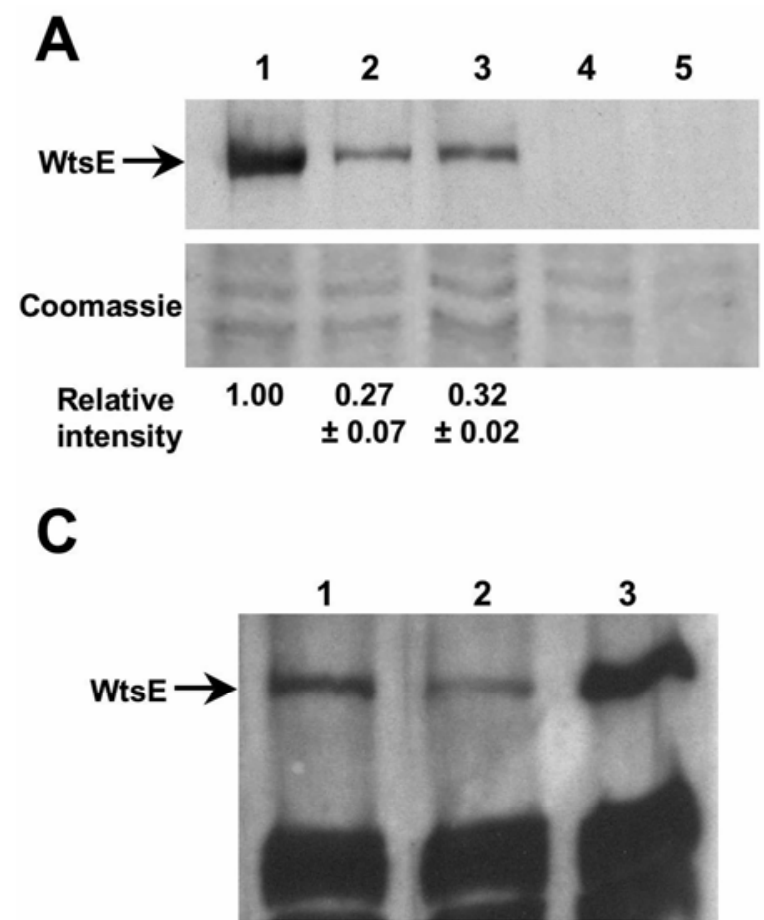

Since WtsE showed very high homology to Erwinia amylovora $\mathrm{Dsp} \mathrm{A} / \mathrm{E}_{E a}$ and anti-DspA/E $\mathrm{E}_{E a}$ antibodies cross-reacted with WtsE, we tested if these effector proteins are functionally interchangeable. pCPP1250, a plasmid containing the $d s p A B / E F_{E a}$ locus (Bogdanove et al. 1998b), was introduced into the wtsE mutant AA005, and virulence on corn seedlings was examined. Both pCPP1250 and pAA007 $w t s E F^{+}$restored virulence to AA005 to about the same degree (Fig. 2), indicating that DspA/E $\mathrm{E}_{E a}$ is able to be translocated by the P. stewartii subsp. stewartii Hrp system and it functions in corn cells. However, pCPP430, a cosmid clone carrying the entire hrp cluster of Erwinia amylovora, including the $d s p A / E$ locus, failed to restore the virulence of AA005 (data not shown), suggesting that the presence of more than one Hrp TTSS in the same cell may interfere with the proper expression or translocation of effectors.

\section{Functional motifs in WtsE and WtsF.}

By using the PSORTII program (Nakai and Kanehisa 1992) and by searching the Pfam (Bateman et al. 2004) and PROSITE (Hulo et al. 2004) databases, we identified several potential motifs in WtsE: a leucine zipper (LZ) at aa 539 to 560, a coiled-coil (CC) region at aa 996 to 1,057, a nuclear localization signal (NLS) at aa 1,358 to 1,361 , and endoplasmic reticulum membrane retention signals (ERMRS) within the last five aa of both the $\mathrm{N}$ - and C-termini (Fig. 5A). Among these motifs, only the ERMRS at the C-terminus was conserved in all the above AvrE family proteins, except DspE $E_{E c a}$, indicating that it may be biologically important (Fig. 5B). Interestingly, the PSORTII program predicted that all AvrE-family proteins, except the AvrE homolog from $R$. solanacearum, may be localized to the plant cell nucleus.

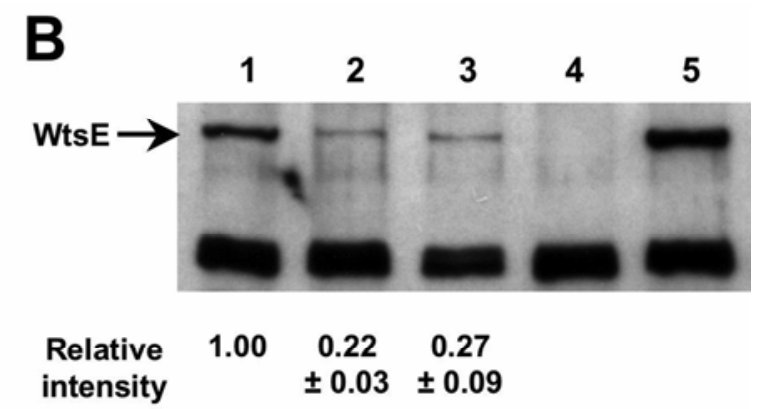

D
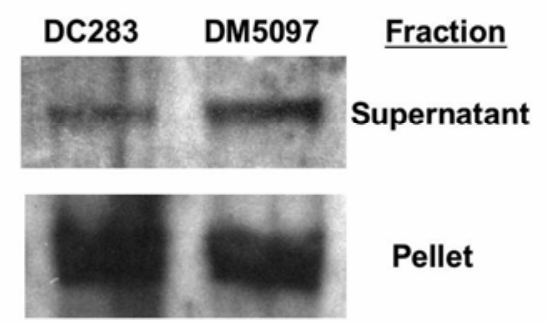

Pellet

Fig. 4. Western blots showing secretion and stability of WtsE in bacteria subcultured in $h r p$-inducing medium at $22^{\circ} \mathrm{C}$. A, Secretion of WtsE into culture supernatants. Lane 1, DC283 wild type; lane 2, DM5040 wtsF::miniTn5gus; lane 3, DM5073 wtsF::miniTn5gus; lane 4, AA005 wtsE; and lane 5, DM711 hrpJ. The lower panel is a Coomassie-stained gel that was used to adjust the relative WstE band intensities for equal sample loading. B, Amount of WtsE in cell pellets of wild-type and $w t s F$ mutant strains. Lanes are the same as in panel A. C, Amount of WtsE in cell pellets showing complementation of a $w t s F$ mutant by ectopic expression of $w t s F^{+}$. Lane 1, DC283; lane 2, DM5073; and lane 3, DM5073 (pWtsF wts $F^{+}$). D, Secretion and stability of the mutant WtsE protein from strain DM5097, which is missing the last 12 amino acids. The Pantoea stewartii subsp. stewartii strains in panels A and B contained plasmid pRF205 $\mathrm{P}_{l a c}-h r p S^{+}$to fully induce the $h r p$ genes and wtsE. In all gels, equal amounts of total protein were loaded, except for strain DM711 hrpJ, which had much less protein in its supernatants. Equal loading was confirmed by bands below WtsE that cross-reacted nonspecifically with anti-DspA/E $E_{E a}$ serum. Numeric values under lanes indicate averages of the relative intensity of each WtsE band. This figure represents the data obtained from at least three independent experiments except for panel D, which was done twice. 
Since the loss of $w t s F$ did not greatly affect pathogenicity and this gene appears to have its own secondary promoter, we were able to examine the effect on virulence of mini-Tn5gus insertions at different locations in $w t s E$ without concern for their polar effects on $w t s F$. All of the new wtsE mutants in Figure 1 were completely avirulent on corn seedlings. This included mutant DM5097, in which the last 12 aa of WtsE, containing the conserved C-terminal ERMRS were replaced by 12 aa encoded by mini-Tn5gus. To eliminate the possibility that the mutation in DM5097 interfered with secretion or stability of the truncated protein, we determined that WtsE was still secreted by and stable in this mutant (Fig. 4D). These results indicate that a full-length $\mathrm{WtsE}$, including the putative $\mathrm{C}$ terminal ERMRS, is required for pathogenicity.

No functional motifs were found for WtsF, the putative chaperone for WtsE. However, BLAST searches revealed several new homologs in addition to $\mathrm{DspB} / \mathrm{F}_{E a}$ and $\mathrm{AvrF}_{\text {Pto }}$; these were $\mathrm{DspF}_{P a g}$ and $\mathrm{DspF}_{E p}$. Interestingly, several additional homologs, such as CesF, were present in pathogenic E. coli strains (Gartner and Schmidt 2004).

\section{Delivery of WtsE into sweet corn leaf tissues}

by $E$. coli carrying the Erwinia chrysanthemi hrp cluster.

E. coli MC4100 carrying cosmid pCPP2156, which contains the entire Erwinia chrysanthemi hrp-gene cluster, promiscuously secretes TTSS effector proteins from a number of plant and animal pathogens into culture supernatants and delivers them into plant cells (Anderson et al. 1999; Ham et al. 1998; Mudgett and Staskawicz 1999). We used this system to deliver WtsE into sweet corn tissues. When vacuum-infiltrated into the leaves of 5-day-old corn seedlings (cv. Seneca Horizon), MC4100 (pCPP2156/pAA008 wtsEF ${ }^{+}$) induced dark, water-

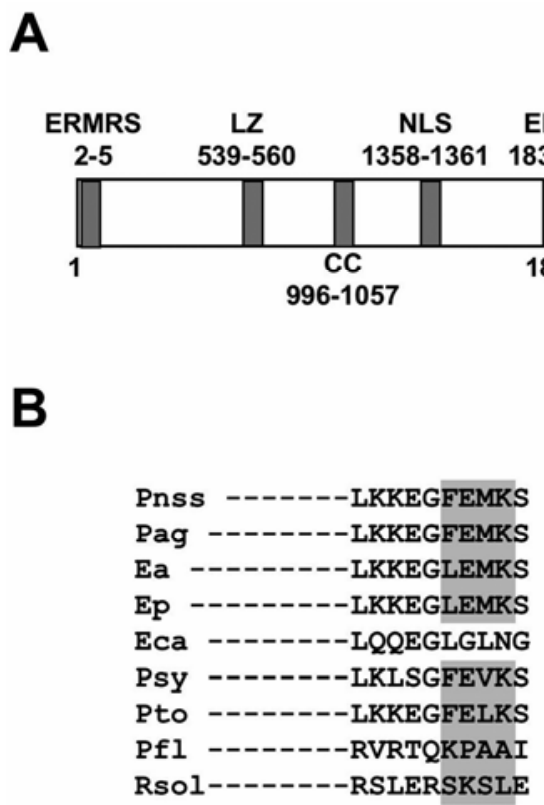

Fig. 5. Predicted functional motifs in WtsE. A, Gray bars indicate a leucine zipper (LZ), a coiled coil region (CC), a nuclear localization signal (NLS), and two endoplasmic reticulum membrane retention signals (ERMRS). Numbers indicate positions in the amino acid (aa) sequence. B, The last 10 aa at the C-termini of AvrE-family proteins from Pantoea stewartii subsp. stewartii (Pnss), P. agglomerans pv. gypsophilae (Pag; GenBank accession number AAF76343), Erwinia amylovora (Ea; AAC04850), E. pyrifoliae (Ep; AAS45452), E. carotovora subsp. atroseptica (Eca; SCRI1043), Pseudomonas syringae pv. syringae B728a (Psy; ZP_00125692), Pseudomonas syringae pv. tomato DC3000 (Pto; T30332), Pseudomonas fluorescens SBW25 (Pfl; AAK74145), and Ralstonia solanacearum (Rsol; NP_522840). The ERMRS predicted by the PSORTII program are shaded. soaked lesions within $12 \mathrm{~h}$ after infiltration (Fig. 6A) and resulted in increased electrolyte leakage (Fig. 6B). In contrast, MC4100 (pCPP2156) without wtsE did not cause any symptoms or leakage. We have named this response in corn WtsEinduced cell death (WICD). To determine if the $E$. coli/ $\mathrm{Hrp}_{E c h}$ delivery system requires $w t s F$, we replaced pAA008 with plasmid pWtsE, which is missing wtsF. MC4100 (pCPP2156/ $\mathrm{pWtsE} w t s E^{+}$) did not cause lesions in corn seedlings. However, addition of $w t s F$ on a separate plasmid, pWtsF, partially restored the ability of this strain to cause water-soaking (Fig. $6 \mathrm{~A}$ ). These results indicate that $\mathrm{WtsF}$ is required for the delivery

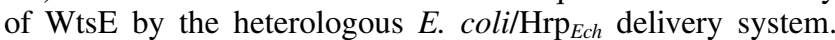
Apparently, redundant chaperones are present in $P$. stewartii subsp. stewartii and are absent in E. coli.

To compare WICD with a known HR in corn, we also vacuum-infiltrated inbred maize line B73 with Xanthomonas oryzae pv. oryzae PXO99 ${ }^{\mathrm{A}}$ carrying the avrRxol gene (Zhao et al. 2004). This strain caused a rapid HR within $12 \mathrm{~h}$ (data not shown), which initially appeared similar to WICD caused by MC4100 (pCPP2156) on B73 and Seneca Horizon. It also produced electrolyte leakage from B73 leaves (Fig. 6C). However, when the inoculum contained cycloheximide $(25 \mu \mathrm{g} / \mathrm{ml})$, which inhibits protein synthesis in eukaryotic cells, the HR caused by AvrRxo1 was inhibited at $18 \mathrm{~h}$ after infiltration (Fig. 6C). Unlike the HR induced by AvrRxo1, WICD was unaffected by cycloheximide (Fig. 6B). Therefore, WICD and AvrRxo1induced HR differ fundamentally in their requirement for new protein synthesis. The typical wtsE-dependent, water-soaking symptoms and electrolyte leakage (Fig. 6D) resulting from infiltration of $P$. stewartii subsp. stewartii at high concentrations $\left(>10^{9} \mathrm{CFU} / \mathrm{ml}\right)$ were likewise insensitive to cycloheximide treatment. This suggests that WICD caused by the $E$. coli delivery system and the water-soaking response caused by $P$. stewartii subsp. stewartii involve similar mechanisms that do not require de novo host protein synthesis.

\section{DISCUSSION}

WtsE is presently the only known effector protein that is essential for pathogenicity of $P$. stewartii subsp. stewartii, even though other effectors may contribute collectively to disease development and bacterial multiplication in corn or adaptation to alternate hosts. In this study, we completed the genetic analysis of the Dsp locus containing wtsEF, demonstrated that WtsE is secreted in culture by the Hrp TTSS, and then showed that delivery of WtsE to corn leaves by a heterologous Hrp system can cause a water soaking-like cell death. We also investigated the role of the WtsF chaperone protein. Our previous study did not include any mutations in wts $F$ or any nonpolar mutations in $w t s E$, so at that time, we were unable to determine if $w t s F$ was also required for full virulence or if part of the avirulent phenotype of wtsE mutants was due to polar effects on $w t s F$. In this study, we found that the loss of $w t s F$ has only a small effect on virulence, indicating that it is not absolutely required for pathogenicity of $P$. stewartii subsp. stewartii or delivery of WtsE into plant cells.

WtsE and its close homologs, DspA/ $\mathrm{E}_{E a}$ and $\mathrm{DspE}_{P a g}$, belong to the AvrE family of effector proteins, members of which are found throughout phytopathogenic species of genera Pseudomonas, Erwinia, and Pantoea. These proteins may be involved in a basic mechanism for damaging host cells to release water and nutrients and could be responsible for the typical symptoms of bacterial diseases, such as water-soaking and necrosis. This notion was supported by our finding that delivery of WtsE alone to sweet corn leaf cells by infiltration of E. coli carrying the Erwinia chrysanthemi hrp cluster resulted in WICD, a rapid cell-death response that mimicked the water-soaking 
symptoms caused by $P$. stewartii subsp. stewartii strains when similarly inoculated. Since we believe that $P$. stewartii subsp. stewartii represents a relatively recently evolved pathogen with very few accessory pathogenicity genes, it is significant that an AvrE-like protein is needed for its pathogenicity. Similarly, the importance of the AvrE family effectors is mirrored by the presence of recognition mechanisms in nonhost plants. For example, $\mathrm{AvrE}_{P t o}$ and $\mathrm{DspA} / \mathrm{E}_{E a}$ cause HR in certain soybean cultivars (Bogdanove et al. 1998b; Lorang and Keen 1995), and $\mathrm{DspA} / \mathrm{E}_{E a}$ causes HR in N. benthamiana (Oh and Beer 2005). Thus, host-specific alleles of DspE may exist.

At this point, our finding that delivery of WtsE can cause WICD in sweet corn is one of the first demonstrations that an AvrE family protein can damage cells of a susceptible host. Concurrent studies on AvrE1 $1_{\text {Pto }}$ (Badel et al. 2006) and $\mathrm{DspA} / \mathrm{E}_{E a}$ (Boureau et al. 2006) have also shown that these effectors can likewise cause cell death in susceptible host plants. However, the nature of cell death caused by any AvrEfamily protein in a susceptible host is still unknown. After comparing WICD caused by E. coli MC4100 (pCPP2156/ pAA008 $w t s E F^{+}$) in sweet corn with the HR induced by $X$. oryzae pv. oryzae $\mathrm{PXO} 99^{\mathrm{A}}$ carrying avrRxol in a resistant maize inbred (B73), we believe that WICD in corn differs fundamentally from an HR. The two responses could be distinguished by their sensitivity to cycloheximide inhibition. The AvrRxo1-induced HR was blocked by cycloheximide, whereas WICD was not (Fig. 6B through D).

We propose that WstE is a multifunctional protein. In susceptible hosts, it may act as both a broad host-range cytotoxin that causes water-soaking and a suppressor of defense responses. WtsE could elicit a programmed cell death-like response in a manner that is cycloheximide resistant and then use its suppressor activity to control the speed of the response and the extent of the damage. In a nonhost, it may elicit a typical HR that masks the slower water-soaking response.

In support of our cytotoxicity hypothesis, we have found that yeast cells expressing $w t s E$ are not viable (data not shown), indicating that WtsE may be generally toxic to eukary-
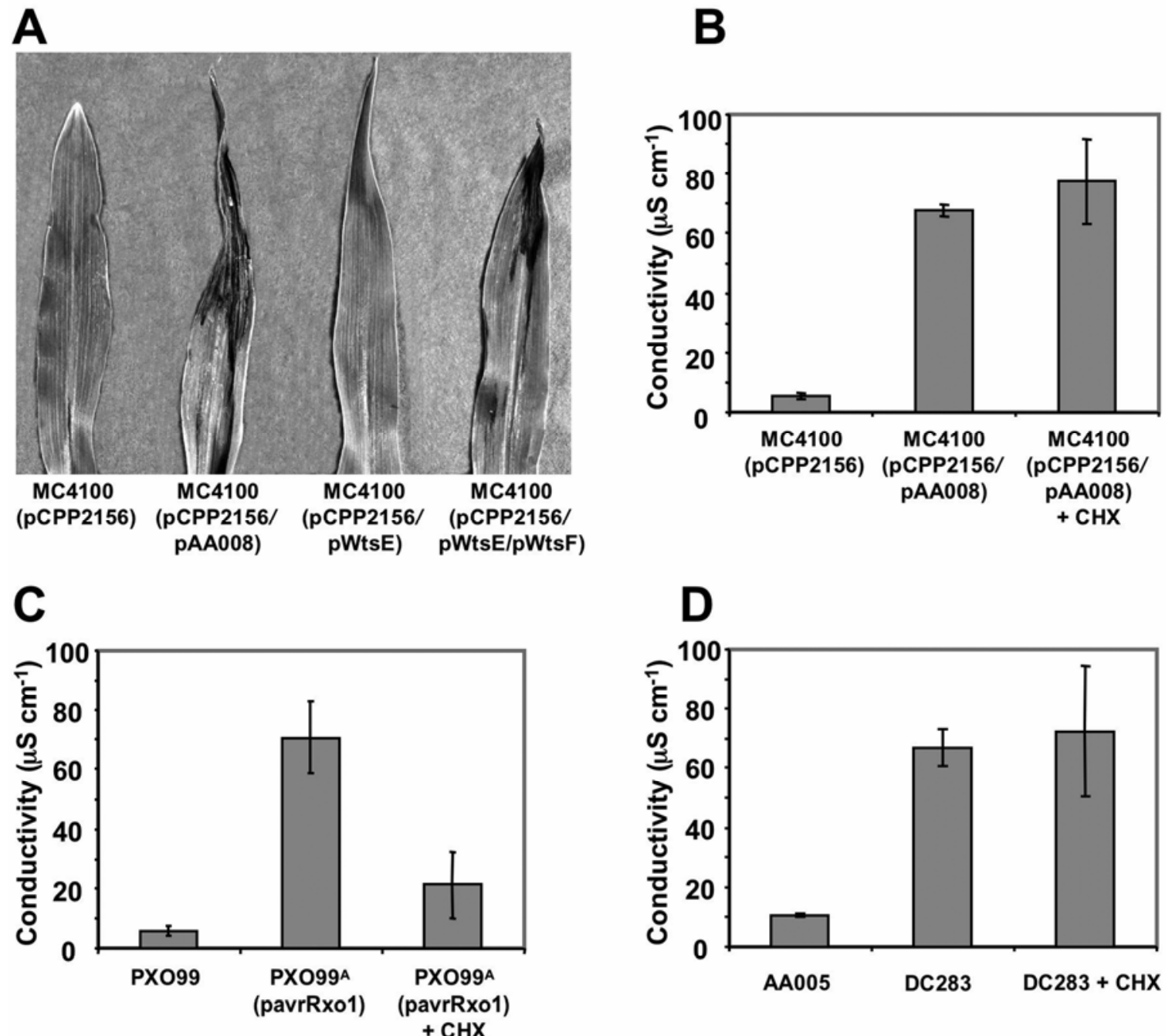

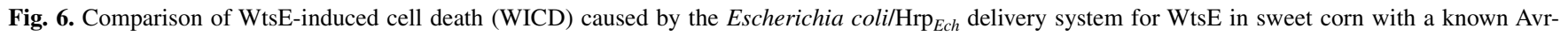
induced hypersensitive response (HR) in maize and water-soaking caused by Pantoea stewartii subsp. stewartii in sweet corn and the sensitivity of each response to cycloheximide (CHX) inhibition. A, WICD symptoms caused by E. coli MC4100 (pCPP2156) carrying various wtsE clones in leaves of sweet corn cv. Seneca Horizon at $24 \mathrm{~h}$ after inoculation. Bacteria were vacuum-infiltrated at an optical density at $600 \mathrm{~nm}=1.0$ into 5 -day-old seedlings. Results represent more than five independent experiments. pCPP2156 contains the entire Erwinia chrysanthemi hrp cluster, pAA008 carries wtsEF ${ }^{+}$, pWtsE carries only $w t s E^{+}$, and $\mathrm{pWtsF}$ carries only $w t s F^{+}$. B, C, and $\mathbf{D}$, Effects of CHX $(25 \mu \mathrm{g} / \mathrm{ml})$ on electrolyte leakage associated with WICD or hypersensitive cell death in 5-day-old seedlings. Conductivity was measured at 16 to $18 \mathrm{~h}$ after infiltration with bacteria, and values are means \pm standard deviation from three replications. Similar results were obtained from at least three independent experiments. B, WICD caused by E. coli MC4100 (pCPP2156/pAA008) on sweet

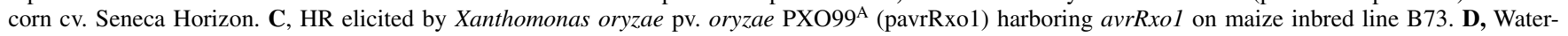
soaking caused by wild-type strain DC283 and wtsE mutant AA005 on sweet corn cv. Seneca Horizon. 
otic cells. Given this scenario, it is possible that the rapidity and severity of WICD in sweet corn may be due to the high dosage of WtsE introduced by the $E$. coli delivery system (in which $>10^{8}$ cells were needed), whereas WtsE normally translocated by $P$. stewartii subsp. stewartii at normal cell concentrations may cause a slower, less severe disruption of cell membrane potential that results in sustained water-soaking. Many TTSS-secreted proteins from animal pathogenic bacteria are known to have cell-death activities in eukaryotic cells. Yersinia YopT and YopE (Aili et al. 2003; Shao et al. 2002), Pseudomonas aeruginosa ExoS, ExoT, and ExoU (Sato and Frank 2004; Sundin et al. 2001), and Bordetella bronchiseptica BopB (Kuwae et al. 2003) are examples of effectors with celldeath activities that involve a variety of different mechanisms. For example, YopT is a cysteine protease that releases RhoGTPase from membranes (Shao et al. 2002); ExoU is a phospholipase that directly causes membrane damage (Sato and Frank 2004); and Yersinia YopJ/P induces host apoptosis by blocking multiple signaling pathways, including the mitogenactivated protein kinase (MAPK) and NFKB pathways in infected cells (Denecker et al. 2001). WtsE does not share any obvious domains or motifs with these effectors, so analogous cytotoxic TTSS-dependent effectors may involve different targets in plant cells.

A recently discovered function of AvrE1 and HopM1 from Pseudomonas syringae pv. tomato is their ability to suppress PAMP-induced, SA-mediated defenses in A. thaliana (DebRoy et al. 2004) and DspA/ $\mathrm{E}_{E a}$ delays PR1 expression in tobacco (Boureau et al. 2006). It is therefore possible that these effectors might target a common signaling component that controls the HR, programmed cell death, or other defense responses in plants. For example, MAPKKK $\alpha$ is involved in both pathogen-associated necrosis and resistant responses to
Pseudomonas syringae pv. tomato in N. benthamiana (del Pozo et al. 2004). Supporting this notion, Meng and associates (2006) identified four receptor-like kinases (RLK) from an apple cDNA library that interact with the N-terminal half of $\mathrm{DspA} / \mathrm{E}_{E a}$ in a yeast two-hybrid system. In similar experiments, we identified an RLK from a sweet corn cDNA library that interacted with the N-terminal half of WtsE (J. H. Ham, D. R. Majerczak, and D. L. Coplin, unpublished data). This is significant because RLKs are involved in a wide range of signal transduction pathways, including defense responses and programmed cell death (Morris and Walker 2003). Therefore, WtsE could interact with an RLK to either suppress the HR or control cell death.

Sequence analysis of WtsE did not identify any potential enzymatic active sites or homologies to known TTSS effectors outside of the AvrE family. However, the analysis indicated that WtsE could be targeted to both the endoplasmic reticulum (ER) membrane and the nucleus. The various motifs found in WtsE include an LZ, a CC region, an NLS, and ERMRSs at both the N- and C-termini (Fig. 5A), and the PSORTII algorithm predicted that WtsE has a $60.9 \%$ probability of being

Table 2. Primers used in this study

\begin{tabular}{ll}
\hline Name & \multicolumn{1}{c}{ Sequences $^{\mathbf{a}}$} \\
\hline wtsE-1 & 5'-TACAGGCTCGAGCGCAGCTT-3' \\
wtsE-2 & 5'-TTAATCGGATCCTCAGCTTT-3' \\
wtsF-1 & 5'-ATGGGCAGGATCCAGACACT-3' \\
wtsF-2 & 5'-CTAAGTTGTATCTAAGAGGCTT-3' \\
wtsF-3 & 5'-CCCAAGCTTGGGCAGAAAGTAATATGATGGAAT-3' \\
wtsF-4 & 5'-CCCAAGCTTGGGCAAATTGCTGTAATAATGC-3' \\
\hline
\end{tabular}

${ }^{a}$ Underlining indicates incorporated restriction sites for cloning $($ Bam HI, GGATCC and HindIII, AAGCTT)

Table 1. Bacterial strains and plasmids used in this study

\begin{tabular}{|c|c|c|}
\hline Name & Description $^{\mathrm{a}}$ & Source or reference \\
\hline \multicolumn{3}{|l|}{ Escherichia coli } \\
\hline MC4100 & $\mathrm{F}^{-}$araD139 $\Delta(\arg F-l a c) U 169$ rpsL150 relA1 flbB5301 fruA25 deoC1 ptsF25 & Casadaban 1976 \\
\hline \multicolumn{3}{|c|}{ Pantoea stewartii subsp. stewartii } \\
\hline DC283 & $\mathrm{SS} 104 \mathrm{Nal}^{\mathrm{r}}$ & Coplin et al. 1986 \\
\hline AA005 & DC283 wtsE::aphT, $\mathrm{Km}^{\mathrm{r}}$ & This study \\
\hline DM711 & DC283 hrpJ79::Tn3HoHoI, Ap ${ }^{r}$ & Frederick et al. 2001 \\
\hline \multicolumn{3}{|c|}{ Xanthomonas oryzae pv. oryzae } \\
\hline PXO99 & Wild-type race 6 & Zhao et al. 2004 \\
\hline PXO99 $^{\mathrm{A}}$ & PXO99 5-azacytidine resistant & Zhao et al. 2004 \\
\hline \multicolumn{3}{|c|}{ A A } \\
\hline pBluescript SK/KS (+) & ColE1 alacZ, $\mathrm{Ap}^{\mathrm{r}}$ & Stratagene, La Jolla, CA, U.S.A. \\
\hline pCR-BluntII-TOPO & TOPO vector (pUC ori), $\mathrm{Km}^{\mathrm{r}}$ & Invitrogen, Carlsbad, CA, U.S.A. \\
\hline pFUS1 & IncP1 plasmid containing a promoterless gus gene, $\mathrm{Tc}^{\mathrm{r}}$ & Reeve et al. 1999 \\
\hline pKNG101 & Suicide vector (oriR6K) containing $s a c B$ mobRK2, $\mathrm{Sm}^{\mathrm{r}}$ & Kaniga et al. 1991 \\
\hline pLAFR3 & IncP cosmid. alacZ, $\mathrm{Tc}^{\mathrm{r}}$ & Staskawicz et al. 1987 \\
\hline pSB315 & Plasmid containing $a p h T$ cassette, $\mathrm{Km}^{\mathrm{r}}$ & Galan et al. 1992 \\
\hline pUTmini-Tn5gus & Mini-Tn5gus in suicide vector pGP704, $\mathrm{Ap}^{\mathrm{r}} \mathrm{Km}^{\mathrm{r}}$ & Fouts et al. 2002 \\
\hline pAA007 & pLAFR3 with 8.9-kb EcoRI/BamHI fragment carrying $w t s E$ and $w t s F, \mathrm{Tc}^{\mathrm{r}}$ & This study \\
\hline pAA008 & $\begin{array}{l}\text { pBluscriptSK(+) with 8.9-kb EcoRI/Bam } \mathrm{HI} \text { fragment carrying wtsE, wtsF, } \\
\text { ORF1, and part of ORF2, Ap }\end{array}$ & This study \\
\hline pAA011 & pAA008 derivative with $a p h T$ insertion in wtsE & This study \\
\hline pavrRxo1 & avrRxol clone in $\mathrm{pHM} 1 ; \mathrm{Sp}^{\mathrm{r}}, \mathrm{Ap}^{\mathrm{r}}$ & Zhao et al. 2004 \\
\hline pCPP1250 & $D s p A / E F_{E a}$ clone in pML123, $\mathrm{Gm}^{\mathrm{r}}$ & Bogdanove et al. 1998b \\
\hline рCРP2156 & Cosmid pCPP19 carrying Erwinia chrysanthemi hrp cluster, $\mathrm{Sp}^{\mathrm{r}}$ & Ham et al. 1998 \\
\hline pDM2791 & 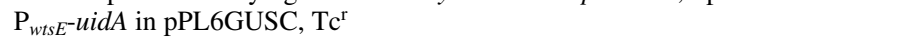 & Merighi et al. 2003 \\
\hline pDM2924 & $\mathrm{P}_{w t s} F^{-u i d A}$ in $\mathrm{pFUS1}, \mathrm{Tc}^{\mathrm{r}}$ & This study \\
\hline pES411 & Cosmid pVK100 carrying right half of $h r p$ cluster & Frederick et al. 2001 \\
\hline pJH019 & 6.5-kb EcoRI/Bam HI fragment carrying $w t s E$ cloned in $\mathrm{pRK} 415, \mathrm{Tc}^{\mathrm{r}}$ & This study \\
\hline pRF205 & 1.7-kb HindIII fragment containing $h r p S$ cloned in $\mathrm{pVK} 100, \mathrm{Tc}^{\mathrm{r}}$ & Frederick et al. 1993 \\
\hline pRK415 & IncP $\alpha l a c Z, \mathrm{Tc}^{\mathrm{r}}$ & Keen et al. 1988 \\
\hline pWtsE & 6.5-kb EcoRI/Bam HI fragment carrying wtsE cloned in pBluescript $\mathrm{SK}(+), \mathrm{Ap}^{\mathrm{r}}$ & This study \\
\hline pWtsF & wts $F$ clone in pCR-BluntII-TOPO, $\mathrm{Ap}^{\mathrm{r}} \mathrm{Km}^{\mathrm{r}}$ & This study \\
\hline
\end{tabular}

${ }^{\mathrm{a}} \mathrm{Nal}^{\mathrm{r}}, \mathrm{Km}^{\mathrm{r}}, \mathrm{Ap}^{\mathrm{r}}, \mathrm{Tc}^{\mathrm{r}}, \mathrm{Sm}^{\mathrm{r}}, \mathrm{Sp}^{\mathrm{r}}$, and $\mathrm{Gm}^{\mathrm{r}}$ indicate resistance to nalidixic acid, kanamycin, ampicillin, tetracycline, streptomycin, spectinomycin, and gentamycin, respectively. 
imported into the nucleus. In Xanthomonas spp., effector proteins in the AvrBs3 family have functional NLSs that are required for both their avirulence and virulence functions (Van den Ackerveken et al. 1996; Yang and Gabriel 1995). It remains to be determined whether any of these predicted motifs are required for WtsE function.

Among the above motifs, only the C-terminal ERMRS was conserved in all but one AvrE family protein (Fig. 5B). Since a miniTn5gus insertion located only $36 \mathrm{bp}$ from the end of $w t s E$ abolished pathogenicity, it is likely that this motif is required for WICD in corn. The uidA fusion in this mutant only added 12 new aa to WtsE, so it is unlikely that a translational fusion could have affected WtsE activity. Moreover, we verified that the stability of WtsE in this mutant was not altered and that it was still secreted into the culture supernatant (Fig. 4D). Since the ER is important for general protein synthesis, folding, and secretion, there are many ways that WtsE could affect host cells by interfering with ER function. We note that many defense-related proteins are synthesized by rough ER in order to be secreted from the cell or into vacuoles. Jelitto-Van Dooren and associates (1999) have shown that an ER-resident chaperone, BiP, is systemically induced in tobacco by bacterial pathogens and that this results in increased production of PR proteins. In animals, ER stress (i.e., alterations of $\mathrm{Ca}^{2+}$ homeostasis and accumulation of misfolded proteins in the ER) can lead to apoptosis (Rao et al. 2004). Thus, one function of WtsE may be to cause ER stress in plant cells.

Some but not all TTSS effectors in animal and plant pathogens have associated molecular chaperone proteins that serve multiple functions. Chaperones have been shown to interact with transcriptional activators that regulate effector protein production, target effectors to the secretion machinery, unfold them so that they can be translocated, and protect them from proteolytic degradation in the bacterial cytoplasm (Feldman and Cornelis 2003; Parsot et al. 2003). Gaudriault and associates (2002) examined the role of $\mathrm{DspB} / \mathrm{F}$ in the secretion of DspA/E by Erwinia amylovora. Their $d s p B / F$ mutant did not secrete DspA/E into culture supernatants and, even though $d s p A / E$ gene expression was normal, their Western blots did not detect DspA/E in cell pellets either. Moreover, the virulence of this strain was greatly reduced. Consequently, they concluded that the primary function of $\mathrm{DspB} / \mathrm{F}$ was to stabilize DspA/E in the bacterial cell. Since the amount of $\mathrm{DspA} / \mathrm{E}$ in pellets and supernatants was below their level of detection, they could not determine if $\mathrm{DspB} / \mathrm{F}$ also was involved in DspA/E secretion. Our results with $P$. stewartii subsp. stewartii were similar, in that mutations in $w t s F$ greatly reduced the amount of $\mathrm{WtsE}$ in both supernatants and pellets at $22^{\circ} \mathrm{C}$ to the same degree, but significant secretion was still observed, especially at $28^{\circ} \mathrm{C}$. This could account for the virulence of $w t s F$ mutants, which were assayed at $29^{\circ} \mathrm{C}$ (Fig. 3). These findings indicate that an important role of WtsF is to stabilize WtsE inside the bacterial cell. However, we cannot rule out the possibility that $\mathrm{WtsF}$ also contributes to WtsE secretion, because the lack of a secretion phenotype in the $w t s F$ mutant may result from a second, redundant chaperone that permits secretion of WtsE. This would be similar to the findings of Guo and associates (2005), who reported that two other chaperones can substitute for ShcO1 in the secretion of HopO1-1 by Pseudomonas syringae. Our observation that $E$. coli $\mathrm{MC} 4100$ (pCPP2156) requires wts $F$ to cause WICD (Fig. 6A) is consistent with this notion.

Recently, Losada and Hutcheson (2005) found that several Pseudomonas syringae effector proteins are specifically degraded by Lon protease, which targets abnormally folded proteins, and that they were protected from degradation by their associated chaperones. Their study included HopM1 and its chaperone, ShcM. Functional lon genes are present in both $P$. stewartii subsp. stewartii and Erwinia amylovora (Eastgate et al. 1995; Ham and Coplin 2003), so it is likely that an important function of DspF/WtsF in the pantoeas and erwinias is to provide protection against degradation by Lon as well as other proteases that may be more active at low temperatures. The presence of an additional $\sigma^{70}$ promoter upstream of the wts $F$ and $d s p B / F$ genes in both $P$. stewartii subsp. stewartii and Erwinia amylovora (Gaudriault et al. 1997) means that these chaperones would be available to stabilize WtsE and DspA/E as soon as they are made during infection.

\section{MATERIALS AND METHODS}

\section{Bacterial strains and plasmids, nucleotide sequence, and growth conditions.}

Bacterial strains and plasmids used in this study are described in Table 1. The sequence of the $P$. stewartii subsp. stewartii Hrp pathogenicity island has been deposited in GenBank (accession number AF282857). Bacteria were routinely grown and maintained in Luria-Bertani (LB) broth and agar (Sambrook et al. 1989) at $28^{\circ} \mathrm{C}$ for $P$. stewartii subsp. stewartii strains and at $37^{\circ} \mathrm{C}$ for $E$. coli strains. IM ( $h r p$-inducing medium) was used for the induction of hrp/wts genes in P. stewartii subsp. stewartii (Frederick et al. 2001). Appropriate antibiotics were supplied as needed at the following concentrations $\left(\mu \mathrm{g} \cdot \mathrm{ml}^{-1}\right)$ : ampicillin, 200; gentamycin, 50; kanamycin, 50; nalidixic acid, 20; spectinomycin, 50; streptomycin, 50; rifampicin, 100; and tetracycline, 25.

\section{General recombinant DNA techniques.}

DNA isolation, restriction enzyme digestion, and ligation were done following standard protocols (Sambrook et al. 1989). Purification of DNA fragments from agarose gels and polymerase chain reaction (PCR) was performed using appropriate Qiagen kits (Qiagen, Valencia, CA, U.S.A.). PCR was done with PfuTurbo polymerase (Stratagene, La Jolla, CA, U.S.A.) for cloning and Taq DNA polymerase (Takara Bio Inc., Tokyo) for general analysis following standard amplification protocols. Plasmids were introduced into bacterial cells either by electroporation using a GenePulser (Bio-Rad Laboratories, Hercules, CA, U.S.A.) apparatus set to $200 \Omega$ and $1.5 \mathrm{kv}$ or by triparental mating as previously described (Merighi et al. 2003).

\section{Plasmid constructions.}

To construct clones of $w t s E F$, the 8.9-kb BamHI/EcoRI fragment from pES411 was cloned into pLAFR3 to create pAA007 and into pBluescript $\mathrm{KS}(+)$ to create pAA008. To make a plasmid with just $w t s E$, a $2.6-\mathrm{kb} N c o \mathrm{I} / E c o$ RI fragment containing the second half of $w t s E$ was obtained by PCR with DNA oligos, wtsE-1 and wtsE-2 (Table 2). This product was then cloned into pCR-BluntII-TOPO (Invitrogen, Carlsbad, CA, U.S.A.). The NcoI site in wtsE and the EcoRI site in the polylinker of pCR-BluntII-TOPO made it possible to use this fragment to replace the $5.0-\mathrm{kb} N c o \mathrm{I} / E c o$ RI fragment of pAA008 to produce plasmid pWtsE, which lacks $w t s F$. The $6.5-\mathrm{kb}$ insert from pWtsE was cloned into pRK415 to produce pJH019. The wtsF ORF was amplified by PCR using DNA oligos, wtsF-1, and wtsF-2 (Table 2), and was then cloned into pCR-BluntIITOPO to generate $\mathrm{pWtsF}$.

To clone the putative $w t s F$ promoter into a gus promoter probe vector, PCR primers wtsF-3 and wtsF-4 (Table 2) were used to amplify a 688-bp fragment from the 5' UTR of $w t s F$. These primers incorporated HindIII sites that were used to clone the amplicon into pBluescript $\mathrm{KS}(+)$. The resulting insert was then removed with BamHI and KpnI and was recloned into BglII/KpnI-cut pFUS1 to produce plasmid pDM2925. 
Construction of a nonpolar wts $E$ mutant.

The 1.0-kb aphT kanamycin-resistance cartridge contained in plasmid pSB315 was isolated as a HincII fragment and was cloned into the NcoI restriction site of $w t s E$ in plasmid pAA008 by blunt-end ligation, yielding a new plasmid, pAA011. The 9.9-kb ApaI/BamHI fragment from pAA011, carrying $w t s E$ disrupted by the $a p h T$ cartridge, was ligated into suicide vector pKNG101 and was recombined into the chromosome of strain DC283, generating the nonpolar wts $E$ mutant strain AA005. The replacement was confirmed by Southern blot analysis (data not shown).

\section{GUS assays.}

GUS activity was assayed fluorometrically using 4-methylumbelliferyl- $\beta$-D-glucuronide (MUG) as previously described (Merighi et al. 2003), using a Wallac Victor2 model 1420 multilabel counter (PerkinElmer Life Sciences, Boston). Specific activity was expressed in GUS units $(1$ unit $=1$ pmol MUG $\min ^{-1}$ at an optical density at $600 \mathrm{~nm}\left[\mathrm{OD}_{600}\right]=1$ per milliliter of culture at $37^{\circ} \mathrm{C}$ ).

\section{Plant assays.}

Virulence assays of $P$. stewartii subsp. stewartii mutants in sweet corn seedlings (Zea mays L. cv. Seneca Horizon) were performed with either the "whorl-inoculation" (Frederick et al. 2001) or "pseudo stem-inoculation" (Ahmad et al. 2001) methods described previously. In the first method, bacterial suspensions containing $0.2 \%$ Tween 40 were added to the whorls of young seedlings without wounding, and disease severity was rated on a 0 to 3 scale $(0=$ no symptoms, $1=$ a few lesions but no ooze, 2 = many lesions and some ooze, and $3=$ confluent lesions and ooze). In the second method, known amounts of inoculum were placed on the stumps of decapitated seedlings and were rated 8 days after inoculation on a scale of 1 to 5 , with $1=$ no symptoms, 2 = scattered lesions, 3 = slight wilting, $4=$ severe wilt, and $5=$ dead. Analysis of variance was conducted to determine the effects of inoculum density and strain on disease severity. Because of significant interaction of strain and inoculum density, individual means were compared, using the interaction-based least significant difference at a 5\% significance level. SPSS 14.0 for Windows (SPSS Inc., Chicago) was used for statistical analysis.

WICD in corn seedlings caused by $E$. coli strains carrying wtsE and the Erwinia chrysanthemi hrp cluster or by P. stewartii subsp. stewartii strains was assayed by infiltrating the bacterial suspensions into the leaves under vacuum. Bacteria were grown overnight, were diluted 50-fold with fresh LB broth, and were further cultured at $28^{\circ} \mathrm{C}$ with vigorous shaking (approximately $150 \mathrm{rpm}$ ) until $\mathrm{OD}_{600}$ values reached approximately 0.6 . They were then suspended in $0.01 \mathrm{M}$ potassium phosphate and $0.2 \%$ Tween 40 buffer ( $\mathrm{pH} 7.0$ ) at approximately $10^{9} \mathrm{CFU} / \mathrm{ml}$ and were held at $28^{\circ} \mathrm{C}$ until used. Plants were grown in a controlled environmental chamber at $29^{\circ} \mathrm{C}(16-\mathrm{h}$ photoperiod, 15,000 lux, $99 \%$ relative humidity). Five-day-old corn seedlings in 5-in pots were inverted, submerged in a beaker containing the bacterial suspension, and were then placed in a bell jar. A partial vacuum was drawn for $3 \mathrm{~min}$ and then released; this procedure was repeated three times. The same method was used to infiltrate $X$. oryzae pv. oryzae PXO99 ${ }^{\mathrm{A}}$ (pavrRxo1) into inbred maize line B73, except the inoculum was prepared from peptone-sucrose agar plates (Zhao et al. 2004)

\section{Measurement of electrolyte leakage.}

Corn leaves were sampled at 16 to $18 \mathrm{~h}$ after infiltration with bacteria, using a cork borer with an inner diameter of 0.8 $\mathrm{cm}$. A leaf disk was removed from the infiltrated area from each of three different corn seedlings and the disks were then placed into a disposable plastic tube containing $10 \mathrm{ml}$ of deionized water. The tube was then placed in a bell jar and a partial vacuum was drawn and released three times, as described above. Three separate replicates were prepared for each treatment. Tubes were then shaken for $1 \mathrm{~h}$ at room temperature on a reciprocal shaker at 50 strokes per min. After shaking, the conductivity of the fluid in each tube was measured using a WTW model Cond 330i conductivity meter with a TetraCon 325 probe (WTW, Weilheim, Germany).

\section{Preparation of protein samples and Western blot analysis.}

To extract and assay WtsE, P. stewartii subsp. stewartii cultures were grown overnight at $28^{\circ} \mathrm{C}$ in $3 \mathrm{ml}$ of $\mathrm{LB}$ broth and were then washed twice and resuspended in $40 \mathrm{ml}$ of IM broth at $\mathrm{OD}_{600}=0.3$. These cultures were grown at $22^{\circ} \mathrm{C}$ for $48 \mathrm{~h}$, until the $\mathrm{OD}_{600}$ was approximately 1.2 and then were centrifuged at $10,000 \times g$ for $20 \mathrm{~min}$ at $4^{\circ} \mathrm{C}$. For the supernatant fraction, the upper $35 \mathrm{ml}$ of supernatant was carefully transferred to a clean tube with $800 \mu \mathrm{l}$ of $50 \mathrm{mM}$ phenylmethylsulphonylfluoride (PMSF) and was centrifuged as before. The upper $30 \mathrm{ml}$ of supernatant was carefully removed, adjusted to $1 \mathrm{mM}$ PMSF and $10 \%$ trichloroacetic acid, and was centrifuged at $10,000 \times g$ for $20 \mathrm{~min}$ at $4^{\circ} \mathrm{C}$. The pellets were rinsed with ice-cold acetone and then were resuspended in $150 \mu \mathrm{l}$ of protein sample buffer $(200$ $\mathrm{mM}$ Tris-Cl, pH 7.2, $100 \mathrm{mM}$ ethylenediaminetetraacetic acid, 1 $\mathrm{M}$ sucrose, and $1 \mathrm{mM}$ PMSF). For the cellular fraction, the pellets from the first centrifugation were resuspended in $150 \mu \mathrm{l}$ of protein sample buffer mixed with an equal volume of $2 \times$ sample denaturing buffer $(300 \mathrm{mM}$ Tris- $\mathrm{Cl}, \mathrm{pH} 6.8,4 \%$ sodium dodecyl sulfate [SDS], 7\% glycerol, and 5\% $\beta$-mercaptoethanol) and then were heated in boiling water for $4 \mathrm{~min}$. The protein concentration of each sample was assayed with the $R C D C$ protein assay system (Bio-Rad), to determine the amount of sample to be loaded for electrophoresis. For Western blots, protein samples were separated by electrophoresis in $8 \%$ SDS-polyacrylamide electrophoresis gels, using a Bio-Rad mini-Protean II gel system (Bio-Rad). Immunodetection of WtsE and $\mathrm{DspA} / \mathrm{E}_{E a}$ was performed with enhanced chemiluminescence Western blotting detection reagents (Amersham Biosciences, Piscataway, NJ, U.S.A.), using anti-DspA/ $\mathrm{E}_{E a}$ antibodies (Bogdanove et al. 1998a) and anti-rabbit HRP secondary antibody (Amersham Biosciences) following the manufacturer's instructions. Kodak 1D image analysis software (Kodak Digital Science, Rochester, NY, U.S.A.) was used to determine band intensities from digital images and chemoluminescence films. Data was normalized to compensate for differences in sample loading, using the intensities of common bands in both Western blots and Coomassiestained gels of each sample. However, supernatants from the hrpJ secretion mutant DM711 contained 90\% less total protein than those of the other strains, so samples from this strain represented an equivalent volume of supernatant.

\section{ACKNOWLEDGMENTS}

We thank S. V. Beer for pCPP1250 and anti-DspA/E $\mathrm{E}_{\mathrm{Ea}}$ antibodies, A. Collmer for E. coli MC4100 (pCPP2156), and G. L. Wang for growth facilities to conduct the HR assays with $X$. oryzae pv. oryzae. This project was supported by the United States-Israel Binational Agricultural Research and Development Fund (BARD), grant number US-3625-01C, and the National Research Initiative of the United States Department of Agriculture Cooperative State Research, Education, and Extension Service, grant number 2005-35319-15328.

\section{LITERATURE CITED}

Ahmad, M., Majerczak, D. R., Pike, S., Hoyos, M. E., Novacky, A., and Coplin, D. L. 2001. Biological activity of harpin produced by Pantoea stewartii subsp. stewartii. Mol. Plant-Microbe Interact. 14:1223-1234. 
Aili, M., Telepnev, M., Hallberg, B., Wolf-Watz, H., and Rosqvist, R. 2003. In vitro GAP activity towards RhoA, Rac1 and Cdc42 is not a prerequisite for YopE induced HeLa cell cytotoxicity. Microb. Pathogenesis 34:297-308

Alfano, J. R., and Collmer, A. 2004. Type III secretion system effector proteins: Double agents in bacterial disease and plant defense. Annu. Rev. Phytopathol. 42:385-414.

Alfano, J. R., Charkowski, A. O., Deng, W. L., Badel, J. L., PetnickiOcwieja, T., van Dijk, K., and Collmer, A. 2000. The Pseudomonas syringae Hrp pathogenicity island has a tripartite mosaic structure composed of a cluster of type III secretion genes bounded by exchangeable effector and conserved effector loci that contribute to parasitic fitness and pathogenicity in plants. Proc. Natl. Acad. Sci. U.S.A. 97:48564861.

Altschul, S. F., Madden, T. L., Schaffer, A. A., Zhang, J., Zhang, Z., Miller, W., and Lipman, D. J. 1997. Gapped BLAST and PSI-BLAST: A new generation of protein database search programs. Nucleic Acids Res. 25:3389-3402

Anderson, D. M., Fouts, D. E., Collmer, A., and Schneewind, O. 1999. Reciprocal secretion of proteins by the bacterial type III machines of plant and animal pathogens suggests universal recognition of mRNA targeting signals. Proc. Natl. Acad. Sci. U.S.A. 96:12839-12843.

Badel, J. L., Nomura, K., Bandyopadhyay, S., Shimizu, R., Collmer, A. He, S. Y. 2003. Pseudomonas syringae pv. tomato DC3000 HopPtoM (CEL ORF3) is important for lesion formation but not growth in tomato and is secreted and translocated by the Hrp type III secretion system in a chaperone-dependent manner. Mol. Microbiol. 49:1239-1251.

Badel, J. L., Shimizu, R., Oh, H.-S., and Collmer, A. 2006. A Pseudomonas syringae pv. tomato avrE1/hopM1 mutant is severely reduced in growth and lesion formation in tomato. Mol. Plant-Microbe Interact. 19:99-111.

Bateman, A., Coin, L., Durbin, R., Finn, R. D., Hollich, V., Griffiths-Jones, S., Khanna, A., Marshall, M., Moxon, S., Sonnhammer, E. L., Studholme, D. J., Yeats, C., and Eddy, S. R. 2004. The Pfam protein families database. Database issue. Nucleic Acids Res. 32:D138-141.

Bogdanove, A. J., Bauer, D. W., and Beer, S. V. 1998a. Erwinia amylovora secretes DspE, a pathogenicity factor and functional AvrE homolog, through the Hrp (type III secretion) pathway. J. Bacteriol. 180:22442247.

Bogdanove, A. J., Kim, J. F., Wei, Z., Kolchinsky, P., Charkowski, A. O., Conlin, A. K., Collmer, A., and Beer, S. V. 1998b. Homology and functional similarity of an hrp-linked pathogenicity locus, $d s p E F$, of $E r$ winia amylovora and the avirulence locus avrE of Pseudomonas syringae pathovar tomato. Proc. Natl. Acad. Sci. U.S.A. 95:1325-1330.

Boureau, T., ElMaarouf-Bouteau, H., Garnier, A., Brisset, M.-N., Perino, C., Pucheu, I., and Barny, M.-A. 2006. DspA/E, a type III effector essential for Erwinia amylovora pathogenicity and growth in planta, induces cell death in host apple and non-host tobacco plants. Mol. PlantMicrobe Interact. 19:16-24.

Casadaban, M. J. 1976. Transposition and fusion of the lac genes to selected promoters in Escherichia coli using bacteriophage lambda and Mu. J. Mol. Biol. 104:541-555.

Coplin, D. L., Frederick, R. D., Majerczak, D. R., and Haas, E. S. 1986. Molecular cloning of virulence genes from Erwinia stewartii. J. Bacteriol. 168:619-623.

DebRoy, S., Thilmony, R., Kwack, Y. B., Nomura, K., and He, S. Y. 2004. A family of conserved bacterial effectors inhibits salicylic acid-mediated basal immunity and promotes disease necrosis in plants. Proc. Natl. Acad. Sci. U.S.A. 101:9927-9932.

del Pozo, O., Pedley, K. F., and Martin, G. B. 2004. MAPKKK $\alpha$ is a positive regulator of cell death associated with both plant immunity and disease. EMBO (Eur. Mol. Biol. Organ.) J. 23:3072-3082.

Denecker, G., Declercq, W., Geuijen, C. A., Boland, A., Benabdillah, R., van Gurp, M., Sory, M. P., Vandenabeele, P., and Cornelis, G. R. 2001. Yersinia enterocolitica YopP-induced apoptosis of macrophages involves the apoptotic signaling cascade upstream of Bid. J. Biol. Chem. 276:19706-19714.

Dolph, P. J., Majerczak, D. R., and Coplin, D. L. 1988. Characterization of a gene cluster for exopolysaccharide biosynthesis and virulence in $\mathrm{Er}$ winia stewartii. J. Bacteriol. 170:865-871.

Eastgate, J. A., Taylor, N., Coleman, M. J., Healy, B., Thompson, L., and Roberts, I. S. 1995. Cloning, expression, and characterization of the lon gene of Erwinia amylovora: Evidence for a heat shock response. J. Bacteriol. 177:932-937.

Feldman, M. F., and Cornelis, G. R. 2003. The multitalented type III chaperones: All you can do with 15 kDa. FEMS (Fed. Eur. Microbiol. Soc.) Microbiol. Lett. 219:151-158.

Fouts, D. E., Abramovitch, R. B., Alfano, J. R., Baldo, A. M., Buell, C. R., Cartinhour, S., Chatterjee, A. K., D’Ascenzo, M., Gwinn, M. L., Lazarowitz, S. G., Lin, N. C., Martin, G. B., Rehm, A. H., Schneider, D.
J., van Dijk, K., Tang, X., and Collmer, A. 2002. Genomewide identification of Pseudomonas syringae pv. tomato DC3000 promoters controlled by the HrpL alternative sigma factor. Proc. Natl. Acad. Sci. U.S.A. 99:2275-2280.

Frederick, R. D., Majerczak, D. R., and Coplin, D. L. 1993. Erwinia stewartii WtsA, a positive regulator of pathogenicity gene expression, is similar to Pseudomonas syringae pv. phaseolicola HrpS. Mol. Microbiol. 9:477-485.

Frederick, R. D., Ahmad, M., Majerczak, D. R., Arroyo-Rodriguez, A. S., Manulis, S., and Coplin, D. L. 2001. Genetic organization of the Pantoea stewartii subsp. stewartii hrp gene cluster and sequence analysis of the $h r p A, h r p C, h r p N$, and wtsE operons. Mol. Plant-Microbe Interact. 14:1213-1222

Galan, J. E., Ginocchio, C., and Costeas, P. 1992. Molecular and functional characterization of the Salmonella invasion gene invA: Homology of InvA to members of a new protein family. J. Bacteriol. 174:43384349

Gartner, J. F., and Schmidt, M. A. 2004. Comparative analysis of locus of enterocyte effacement pathogenicity islands of atypical enteropathogenic Escherichia coli. Infect. Immun. 72:6722-6728.

Gaudriault, S., Malandrin, L., Paulin, J. P., and Barny, M. A. 1997. DspA an essential pathogenicity factor of Erwinia amylovora showing homology with AvrE of Pseudomonas syringae, is secreted via the Hrp secretion pathway in a DspB-dependent way. Mol. Microbiol. 26:1057-1069.

Gaudriault, S., Paulin, J. P., and Barny, M. A. 2002. The DspB/F protein of Erwinia amylovora is a type III secretion chaperone ensuring efficient intrabacterial production of the Hrp-secreted DspA/E pathogenicity factor. Mol. Plant Pathol. 3:313-320.

Guo, M., Chancey, S. T., Tian, F., Ge, Z., Jamir, Y., and Alfano, J. R. 2005 Pseudomonas syringae type III chaperones ShcO1, ShcS1, and ShcS2 facilitate translocation of their cognate effectors and can substitute for each other in the secretion of HopO1-1. J. Bacteriol. 187:4257-4269.

Ham, J. H., and Coplin, D. L. 2003. Lon protease is a negative regulator of the Hrp type III protein secretion system in Pantoea stewartii subsp. stewartii. Phytopathology 93:S32.

Ham, J. H., Bauer, D. W., Fouts, D. E., and Collmer, A. 1998. A cloned Erwinia chrysanthemi Hrp (type III protein secretion) system functions in Escherichia coli to deliver Pseudomonas syringae Avr signals to plant cells and to secrete Avr proteins in culture. Proc. Natl. Acad. Sci. U.S.A. 95:10206-10211.

Holeva, M. C., Bell, K. S., Hyman, L. J., Avrova, A. O., Whisson, S. C., Birch, P. R. J., and Toth, I. K. 2004. Use of a pooled transposon mutation grid to demonstrate roles in disease development for Erwinia carotovora subsp. atroseptica putative type III secreted effector (DspE/A) and helper (HrpN) proteins. Mol. Plant-Microbe Interact. 17:943-950.

Hulo, N., Sigrist, C. J., Le Saux, V., Langendijk-Genevaux, P. S., Bordoli, L., Gattiker, A., De Castro, E., Bucher, P., and Bairoch, A. 2004. Recent improvements to the PROSITE database. Database issue. Nucleic Acids Res. 32:D134-137.

Jelitto-Van Dooren, E. P., Vidal, S., and Denecke, J. 1999. Anticipating endoplasmic reticulum stress. A novel early response before pathogenesisrelated gene induction. Plant Cell 11:1935-1944.

Kaniga, K., Delor, I., and Cornelis, G. R. 1991. A wide-host-range suicide vector for improving reverse genetics in gram-negative bacteria: Inactivation of the blaA gene of Yersinia enterocolitica. Gene 109:137-141.

Keen, N. T., Tamaki, S., Kobayashi, D., and Trollinger, D. 1988. Improved broad-host-range plasmids for DNA cloning in gram-negative bacteria. Gene 70:191-197.

Kuwae, A., Ohishi, M., Watanabe, M., Nagai, M., and Abe, A. 2003. BopB is a type III secreted protein in Bordetella bronchiseptica and is required for cytotoxicity against cultured mammalian cells. Cell. Microbiol. 5:973-983.

Lorang, J. M., and Keen, N. T. 1995. Characterization of avrE from Pseudomonas syringae pv. tomato: A hrp-linked avirulence locus consisting of at least two transcriptional units. Mol. Plant-Microbe Interact. 8:4957.

Lorang, J. M., Shen, H. Kobayashi, D., Cooksey, D., and Keen, N.T. 1994 avrA and avrE in Pseudomonas syringae pv. tomato PT23 play a role in virulence on tomato plants. Mol. Plant-Microbe Interact. 7:508-515.

Losada, L. C., and Hutcheson, S. W. 2005. Type III secretion chaperones of Pseudomonas syringae protect effectors from Lon-associated degradation. Mol. Microbiol. 55:941-953.

Meng, X., Bonasera, J. M., Kim, J. F., Nissinen, R. M., and Beer, S. V. 2006. Apple proteins that interact with DspA/E, a pathogenicity effector of Erwinia amylovora, the fire blight pathogen. Mol. Plant-Microbe Interact. 19:53-61.

Merighi, M., Majerczak, D. R., Stover, E. H., and Coplin, D. L. 2003. The HrpX/HrpY two-component system activates hrpS expression, the first step in the regulatory cascade controlling the Hrp regulon in Pantoea stewartii subsp. stewartii. Mol. Plant-Microbe Interact. 16:238-248. 
Mor, H., Manulis, S., Zuck, M., Nizan, R., Coplin, D. L., and Barash, I. 2001. Genetic organization of the hrp gene cluster and $d s p A E / B F$ operon in Erwinia herbicola pv. gypsophilae. Mol. Plant-Microbe Interact. 14:431-436.

Morris, E. R., and Walker, J. C. 2003. Receptor-like protein kinases: The key to response. Curr. Opin. Plant Biol. 6:339-342.

Mudgett, M. B. 2005. New insights to the function of phytopathogenic bacterial type III effectors in plants. Annu. Rev. Plant Biol. 56:509531 .

Mudgett, M. B., and Staskawicz, B. J. 1999. Characterization of the Pseudomonas syringae pv. tomato AvrRpt 2 protein: Demonstration of secretion and processing during bacterial pathogenesis. Mol. Microbiol. 32:927-941.

Nakai, K., and Kanehisa, M. 1992. A knowledge base for predicting protein localization sites in eukaryotic cells. Genomics 14:897-911.

Oh, C.-S., and Beer, S. V. 2005. Molecular genetics of Erwinia amylovora involved in the development of fire blight. FEMS (Fed. Eur. Microbiol. Soc.) Microbiol. Lett. 253:185-192.

Parsot, C., Hamiaux, C., and Page, A. L. 2003. The various and varying roles of specific chaperones in type III secretion systems. Curr. Opin. Microbiol. 6:7-14.

Preston, G. M., Bertrand, N., and Rainey, P. B. 2001. Type III secretion in plant growth-promoting Pseudomonas fluorescens SBW25. Mol. Microbiol. 41:999-1014.

Rao, R. V., Ellerby, H. M., and Bredesen, D. E. 2004. Coupling endoplasmic reticulum stress to the cell death program. Cell Death Differ. 11:372-380.

Reese, M. G. 2001. Application of a time-delay neural network to promoter annotation in the Drosophila melanogaster genome. Comput. Chem. 26:51-56.

Reeve, W. G., Tiwari, R. P., Worsley, P. S., Dilworth, M. J., Glenn, A. R., and Howieson, J. G. 1999. Constructs for insertional mutagenesis, transcriptional signal localization and gene regulation studies in root nodule and other bacteria. Microbiology 145:1307-1316.
Sambrook, J., Fritsch, E. F., and Maniatis, T. 1989. Molecular Cloning: A Laboratory Manual. Cold Spring Harbor Laboratory Press, Cold Spring Harbor, NY, U.S.A.

Sato, H., and Frank, D. W. 2004. ExoU is a potent intracellular phospholipase. Mol. Microbiol. 53:1279-1290.

Shao, F., Merritt, P. M., Bao, Z., Innes, R. W., and Dixon, J. E. 2002. A Yersinia effector and a Pseudomonas avirulence protein define a family of cysteine proteases functioning in bacterial pathogenesis. Cell 109:575-588.

Staskawicz, B. J., Dahlbeck, D., Keen, N. T., and Napoli, C. 1987. Molecular characterization of cloned avirulence genes from race 0 and race 1 of Pseudomonas syringae pv. glycinea. J. Bacteriol. 155:1060-1070.

Sundin, C., Henriksson, M. L., Hallberg, B., Forsberg, A., and FrithzLindsten, E. 2001. Exoenzyme T of Pseudomonas aeruginosa elicits cytotoxicity without interfering with Ras signal transduction. Cell Microbiol. 3:237-246.

Van den Ackerveken, G., Marois, E., and Bonas, U. 1996. Recognition of the bacterial avirulence protein AvrBs3 occurs inside the host plant cell. Cell 87:1307-1316.

Yang, Y., and Gabriel, D. W. 1995. Xanthomonas avirulence/pathogenicity gene family encodes functional plant nuclear targeting signals. Mol. Plant-Microbe Interact. 8:627-631.

Zhao, B., Ardales, E. Y., Raymundo, A., Bai, J., Trick, H. N., Leach, J. E. and Hulbert, S. H. 2004. The avrRxol gene from the rice pathogen Xanthomonas oryzae pv. oryzicola confers a nonhost defense reaction on maize with resistance gene Rxo1. Mol. Plant-Microbe Interact. 17:771779 .

\section{AUTHOR-RECOMMENDED INTERNET RESOURCES}

Berkeley Drosophila Genome Project website: www.fruitfly.org/seq tools/promoter.html

PSORTII program: psort.ims.u-tokyo.ac.jp 